\title{
Lateral distortional buckling of cellular composite-beams
}

\section{Flambagem lateral com distorção de vigas mistas celulares}
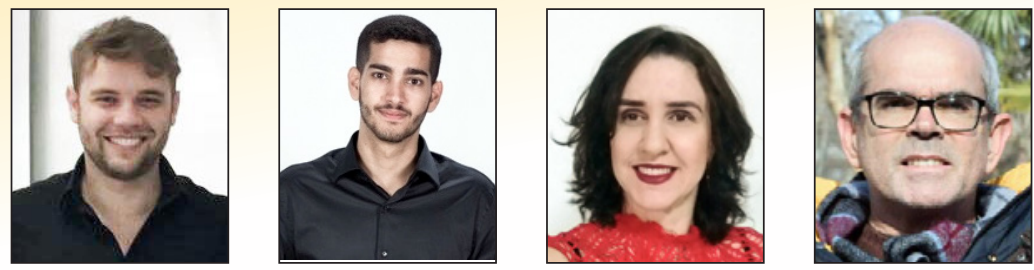

A. D. PIASSI a

allan_piassi@yahoo.com.br

J. V. DIAS b

joaovfdias@gmail.com

A. F. G. CALENZANI a afcalenzani@gmail.com

F. C. C. MENANDRO a fernando.menandro@ufes.br

\begin{abstract}
In the region of negative bending moments of continuous and semi-continuous steel and concrete composite beams, the inferior portion of the steel section is subjected to compression while the top flange is restricted by the slab, which may cause a global instability limit state know as lateral distortional buckling (LDB) characterized by a lateral displacement and rotation of the bottom flange with a distortion of the section's web when it doesn't have enough flexural rigidity. The ABNT NBR 8800:2008 provides an approximate procedure for the verification of this limit state, in which the resistant moment to LDB is obtained from the elastic critical moment in the negative moment region. One of the essential parameters for the evaluation of the critical moment is the composite beam's rotational rigidity. This procedure is restricted only to to steel and concrete composite beams with sections that have plane webs. In this paper, an equation for the calculation of the rotational rigidity of cellular sections was developed in order to determine the LDB elastic critical moment. The formulation was verified by numerical analyses performed in ANSYS and its efficiency was confirmed. Finally, the procedure described in ABNT NBR 8800:2008 for the calculation of the critical LDB moment was expanded to composite beams with cellular sections in a numerical example with the appropriate modifications in geometric properties and rotational rigidity.
\end{abstract}

Keywords: cellular profile, rotational stiffness, lateral distortional buckling, elastic critical moment.

\section{Resumo}

Na região de momento negativo das vigas mistas de aço e concreto contínuas e semicontínuas, a parte inferior do perfil de aço está sujeita à compressão, enquanto a mesa superior está travada pela laje, o que pode ocasionar um estado limite de instabilidade global denominado flambagem lateral com distorção (FLD) caracterizado por deslocamento lateral e giro da mesa inferior mediante a distorção ocorrida na alma do perfil de aço caso esta não possua rigidez flexional suficiente. A ABNT NBR 8800:2008 fornece um procedimento aproximado para verificação desse estado limite pelo qual se obtém o momento fletor resistente à FLD a partir do momento crítico elástico da região de momento negativo. Uma grandeza fundamental para se chegar ao valor do momento crítico elástico é a rigidez rotacional da viga mista. O procedimento da ABNT NBR 8800:2008 se restringe somente às vigas mistas de aço e concreto com perfis de aço de alma cheia. Nesse trabalho, uma formulação analítica para o cálculo da rigidez rotacional da alma de um perfil celular foi desenvolvida com vistas à determinação do momento crítico elástico à FLD. A formulação foi verificada por análises numéricas desenvolvidas no ANSYS que comprovaram a sua eficiência. Por fim, o procedimento descrito na ABNT NBR 8800:2008 para cálculo do momento crítico à FLD é estendido a vigas mistas com perfil de aço celular em um exemplo numérico com as devidas modificações nas propriedades geométricas e na rigidez rotacional.

Palavras-chave: perfil celular, rigidez rotacional, flambagem lateral com distorção, momento crítico elástico. 


\section{Introduction}

A steel and concrete composite beam, according to Brazilian Standard ABNT NBR 8800:2008 [1], consists of a steel component symmetric with respect to the flexure axis, which can be an I profile of a truss, with a concrete slab on top of its superior flange. There must be mechanical connection through shear connectors between the steel component and the slab, such that both can work together to resist flexure.

In continuous and semi-continuous steel and concrete composite beams, the regions close to internal supports are subjected to hogging moments and, since the inferior flange and part of the web are compressed, the beam will be subject to lateral-torsional buckling (LTB), local flange buckling (LFB), and local web buckling (LWB).

The Brazilian Standard ABNT NBR 8800:2008 [1] provides and approximate procedure for the verification of the limit state for lateral-torsional buckling (LTB), similar to the European Standard EN 1994-1-1:2004 [2], based on the behavior of the inverted $\mathrm{U}$-frame mechanism, from which the resisting flexural moment to LTB is obtained from the critical elastic moment of the hogging moment region. A fundamental parameter to compute the critical elastic moment is the rotational stiffness of the composite beam. This procedure from the standard is restricted to composite beams of continuous plane webs. Research on lateral-torsional buckling of composite beams with cellular profiles is still recent.

\section{Lateral-torsional buckling}

Lateral-torsional buckling will happen at the hogging moment regions of continuous and semi-continuous composite beams due to compression of the bottom flange and the tendency towards buckling with respect to the major axis of the flange, since buckling with respect to the minor axis is restricted by the profile web. If the web is not sufficiently stiff against flexure it will displace and the compressed flange will buckle laterally, accompanied by torsion. (Figure 1)

The model considered by ABNT NBR 8800:2008 [1] to represent the behavior of a composite beam with respect to LTB is the inverted U-frame model. This mechanism is formed by two or more adjacent parallel beams connected to the same supported slab, such as in Figure 2.

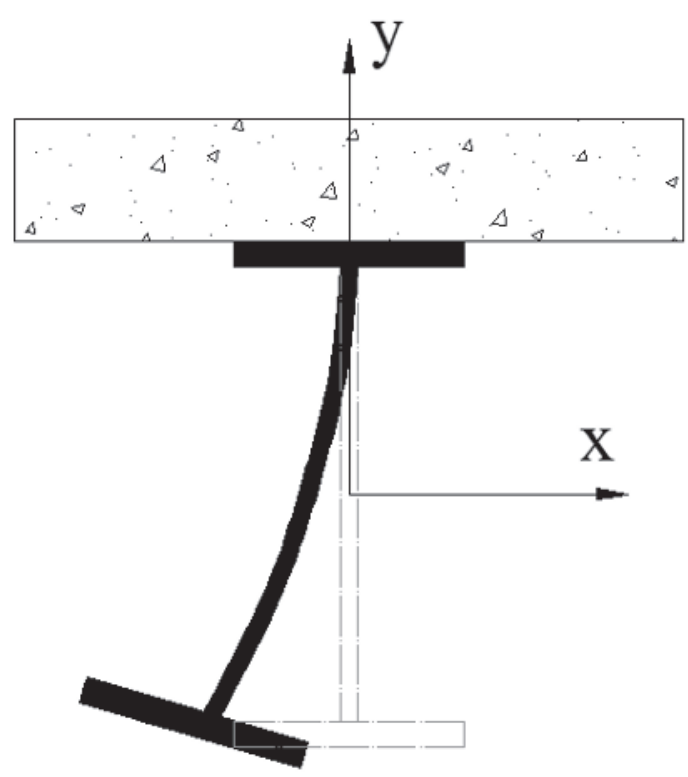

Figure 1

Lateral torsional buckling [3]

Adapted by the authors

Experimental results of Fan [5] proved that the inverted U-frame model is more adequate to represent the behavior of a composite beam subject to LTB than the T model of only one steel beam connected to the concrete slab by shear connectors. The U-frame model is able to depict more realistically the restrictions imposed to the lateral displacement and to the torsion of the bottom flange of the steel profile by the concrete slab. The stiffness of this mechanism with respect to the longitudinal axis of the steel profiles is called rotational stiffness $\left(k_{r}\right)$.

According to Johnson [6], the rotational stiffness of a composite beam associates a perturbation force $\mathrm{F}$ acting on the bottom flange of the steel profiles with the rotation $\theta$ and, consequently, with the lateral displacement $\delta$ in these flanges such as in Figure 3. This stiffness, applied to a rotational spring located at the top flange of a beam, allows for the reproduction of the influence of the U-frame mechanism on the LTB strength and is obtained by unit length of the beam, associating the moment at point $A$, located at the

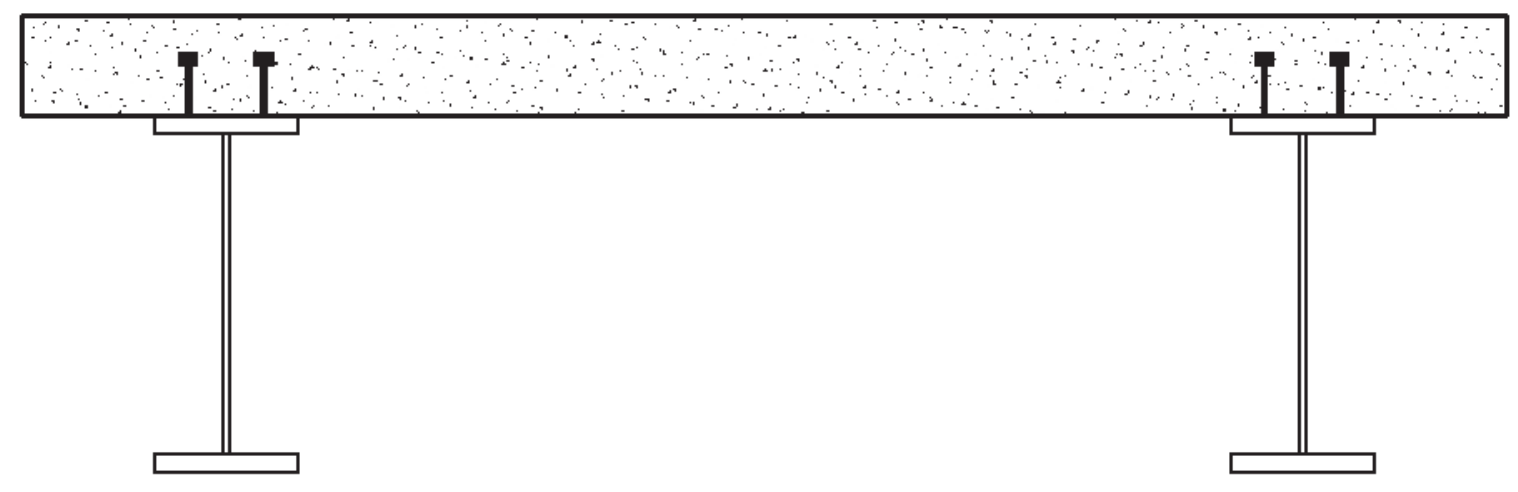

Figure 2

Inverted U-frame mechanism [4] 
geometric center of the top flange, to the rotation angle, such as in equation 1 :

$$
k_{r}=\frac{F h_{0}}{\delta / h_{0}}
$$

where $F$ is the applied force on the bottom flange, $h_{0}$ is the height of the steel profile, measured between centroids of the flanges.

The determination of the rotational stiffness $\left(k_{r}\right)$ directly from equation (1) depends on high complexity experimental or numerical analyses. ABNT NBR 8800:2008 [1] provides a direct simplified method to solve this problem, due to Johnson [6]. The method consists in obtaining the isolate rotations due to transverse flexure of the concrete slab, the web distortion, and the shear connector strain. Thus, the rotational stiffness value can be obtained as a function of the flexural stiffness of the slab $\left(k_{1}\right)$, the flexural stiffness of the profile web $\left(k_{2}\right)$, and the flexural stiffness of the shear connection $\left(k_{3}\right)$, according to the well known expression for springs connected in series.

$\frac{1}{k_{r}}=\frac{1}{k_{1}}+\frac{1}{k_{2}}+\frac{1}{k_{3}}$

For the flexural stiffness of the cracked concrete slab (in the longitudinal steel profiles direction) the slab can be considered as a beam fixed on the steel profiles, Johnson [6]. Applying unit rotations on the fixed ends, the moments that arise are the stiffness values sought at each support, as in Figure 4. Generalizing, the flexural stiffness of the slab by unit length is:

$k_{1}=\frac{\alpha(E I)_{2}}{a}$

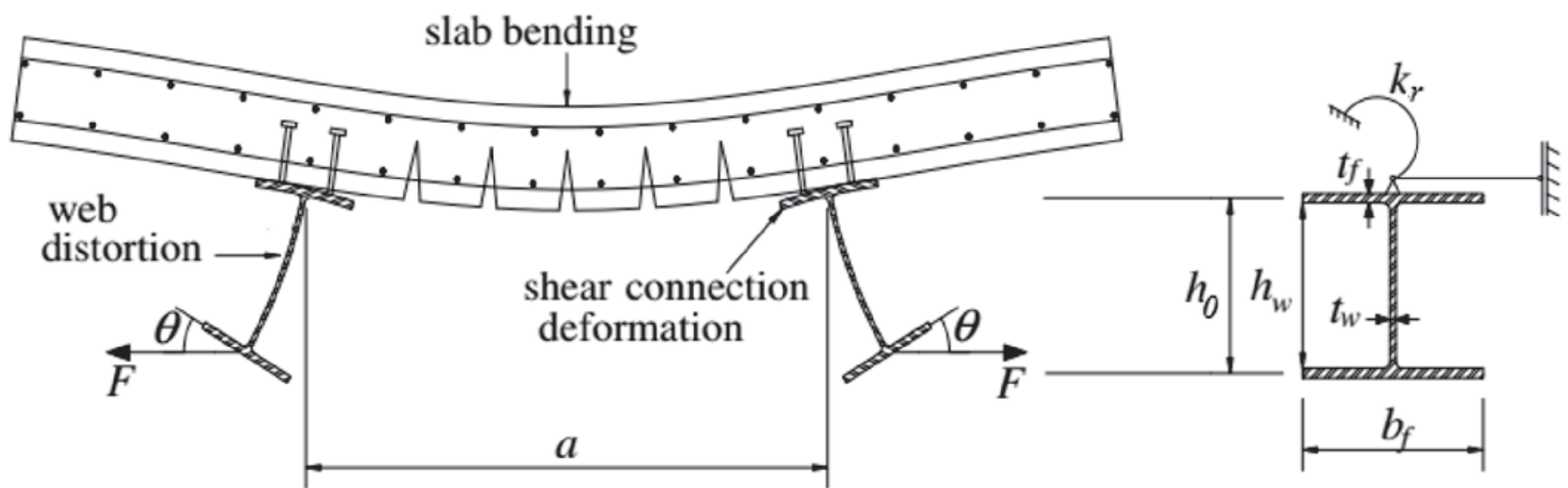

\section{Figure 3}

Rotational stiffness of a composite beam [8]

Adapted by the authors

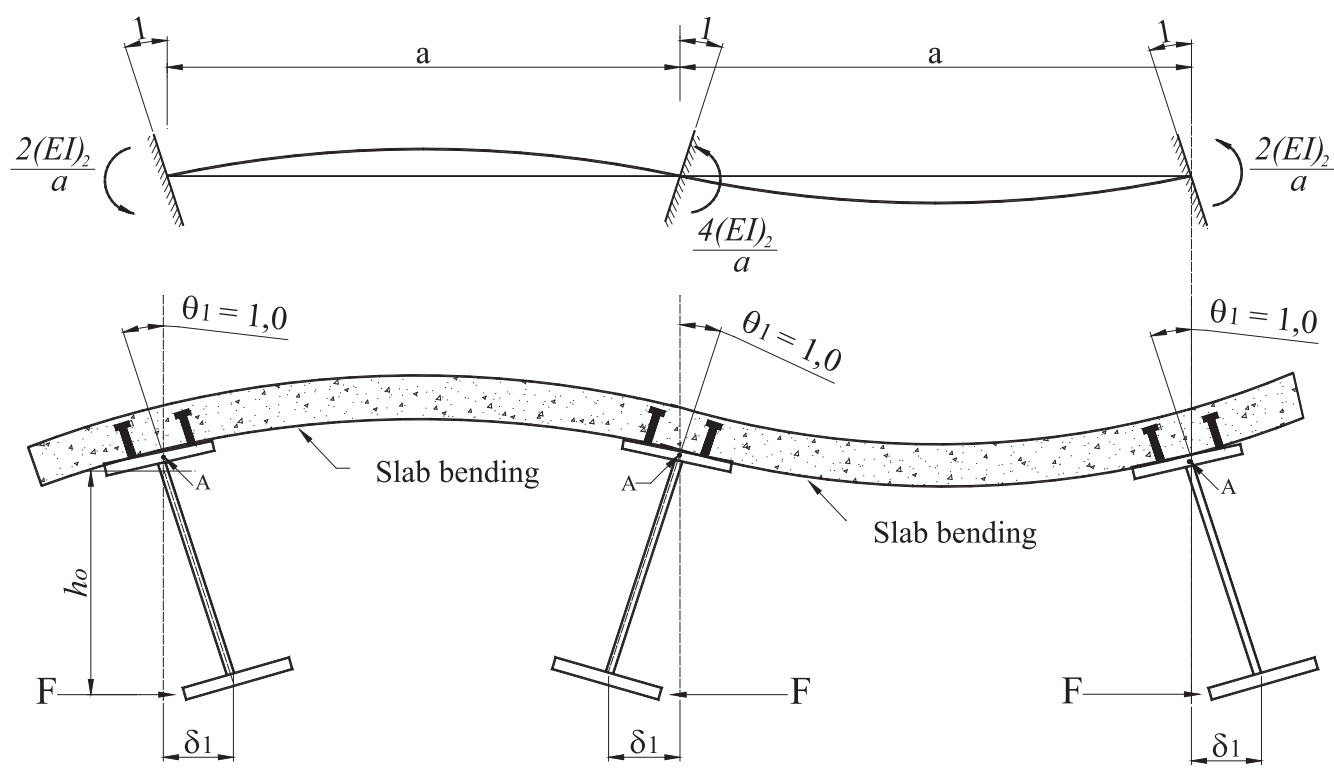

\section{Figure 4}

Flexural stiffness of the cracked slab [4] 


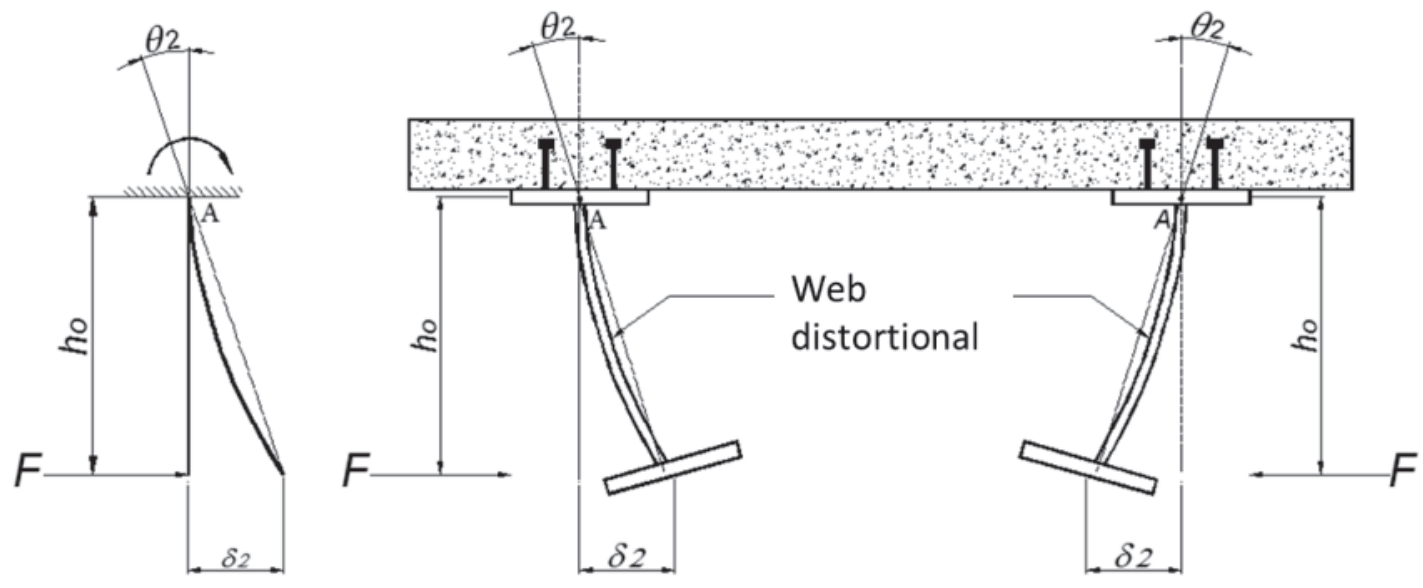

\section{Figure 5}

Rotational stiffness of the profile web [4]

Where $\alpha$ is a coefficient which depends of the analyzed position on the beam, i.e.: if the beam is an edge beam a equals 2 , and if the beam is an internal beam a equals 3 (for inner beams on a floor with four or more similar parallel beams, 4 may also be used). The term $(E I)_{2}$ is the flexural stiffness of the homogenized composite slab section which does not take into account the portion of concrete under tension, by unit length, taken as the lower value between the stiffness at the center of the span and the stiffness at the internal support. The a value is the distance between parallel beams.

For the flexural stiffness of the steel profile web, as can be seen at Figure 5, the web is considered as a plate fixed at the centroid of the top flange and free at the centroid of the bottom flange, Johnson [6]. The horizontal force $F$ which acts on the bottom flange causes the displacement $\delta_{2}$. The flexural stiffness per unit length of the plate will thus be:

$k_{2}=\frac{E_{a} t_{w}^{3}}{4 h_{0}\left(1-v_{a}^{2}\right)}$

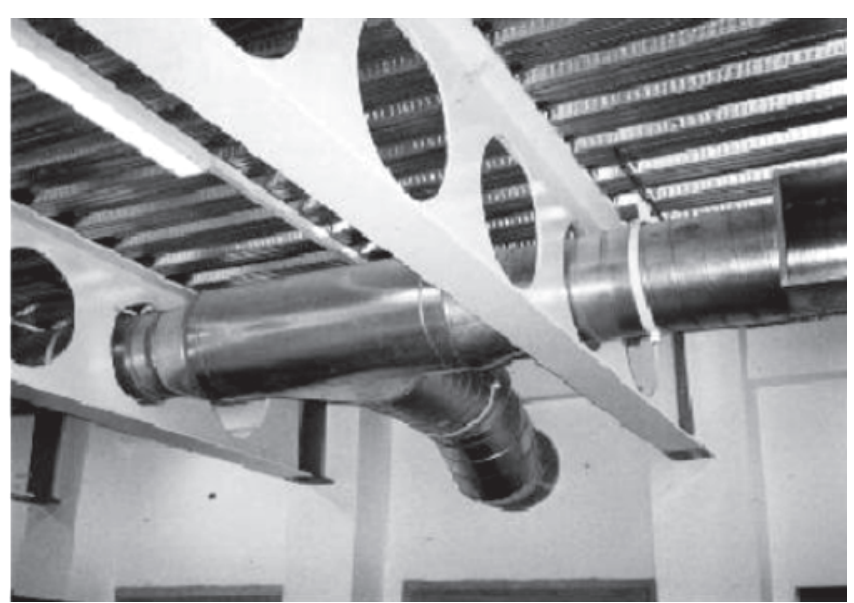

Figure 6

Application of composite beam with cellular profile [10] where $t_{w}$ is the web thickness, $E_{a}$ is Young's Modulus, and $v_{a}$ Poisson's Coefficient for the steel.

The shear connection stiffness, $k_{3}$, depends on a large number of factors, which makes it practically impossible to obtain its value analytically. This stiffness is usually very high, and can be dismissed by the design methods, including ABNT NBR 8800:2008 [1]. According to Johnson and Molenstra [7], experiments with bridge composite beams showed that the shear connection stiffness affects the total stiffness in less than one percent.

Calenzani et al. [8] presented a formulation to determine the rotational stiffness of composite beams with sinusoidal web profiles, based on experimental results on four prototypes representative of the inverted U-frame mechanism, used for the development and calibration of a numerical finite element model. To evaluate the parameters that influence the rotational stiffness of these beams, 68 numerical models were implemented.

The elastic critical moment to LTB $\left(M_{c r}\right)$ is defined by Equation 5 according to ABNT NBR 8800:2008 [1], which uses Roik, Hanswille, and Kina [9] formulation.

$M_{c r}=\alpha_{g} \frac{C_{d i s t}}{L} \sqrt{\left(G J+\frac{k_{r} L^{2}}{\pi^{2}}\right) E I_{a f, y}}$

where $G$ is the shear modulus for the steel; $L$ is the length of the beam between vertical supports (both flanges of the steel beam are required to be laterally constrained at these supports), $J$ is the torsional constant of the steel profile, $l_{\text {af, } y}$ is the moment of inertia of the bottom flange of the steel profile with respect to the $y$ axis, $C_{\text {dist }}$ is a coefficient which depends on the moment distribution on the span $L$, $\alpha_{g}$ is a factor related to the geometry of the composite beam cross section, $k_{r}$ is the rotational stiffness of the composite beam.

Composite beams with cellular steel profile, Figure 6, are currently utilized in construction due to their clear advantages, such as: good strength with respect to their weight as a consequence of the increase in height, possibility of long spans, service ducts passage through the web openings, among others. These beams, though, are not covered by most design standards, making it necessary to search for design guidelines such as the one by Lawson and 


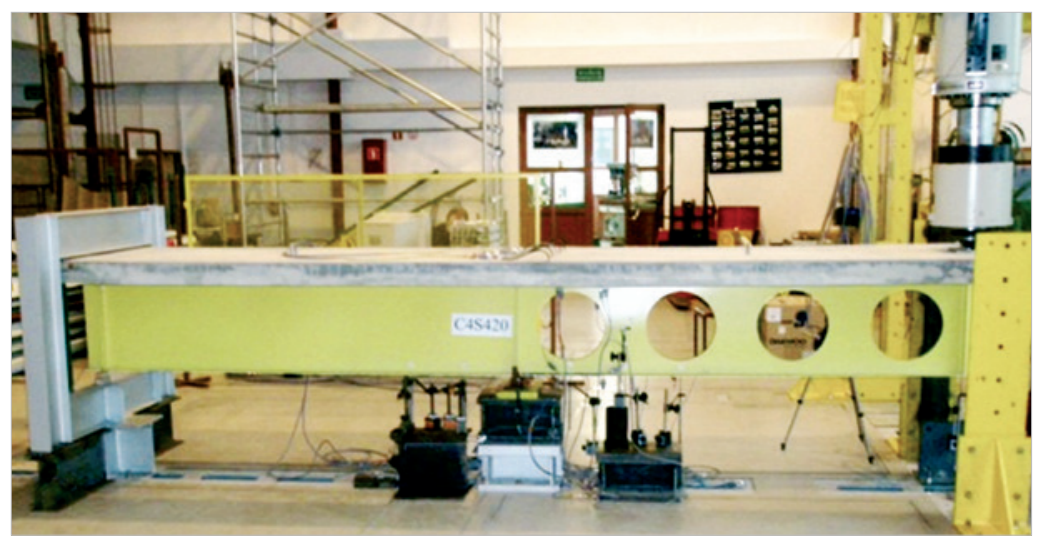

A Composite beams with cellular profile prototypes

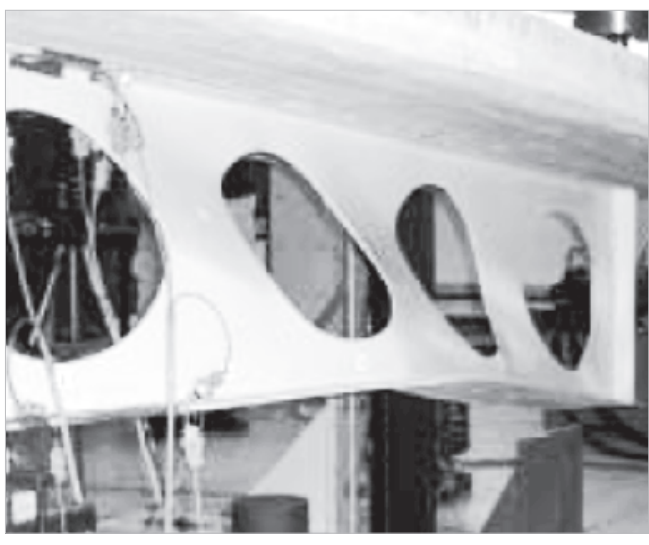

B LTB Collapse

\section{Figure 7}

Experiments with composite beams with cellular profiles [12]

Hicks [10] and Ward's [11]. Not much research on LTB of composite beams with cellular steel profiles in the region of hogging moments is found in the literature.

Gizejowski and Khalil [12] developed an experimental work to evaluate the behavior of composite steel and concrete beams with steel profiles containing openings on their web, subject to hogging moment. Twelve prototypes were tested, considering six with long spans to represent cases in which flexure controls the behavior of the beam, and six with short spans to consider the shear effect. Three different types of openings were analyzed: rectangular, hexagonal, and circular openings. In all tests, Gizejowski and Khalil [12] observed the lateral-torsional buckling mode (Figure 7). The lateral displacement with small distortion strain on the steel profile web predominated for the long span beams with circular and hexagonal openings. For the beams with rectangular openings, and for all the short spans, predominated the torsional buckling with small lateral displacement of the steel profile web.

In this work, an analytical formulation for the rotational stiffness of cellular steel profile webs is developed, for the determination of the LTB elastic critical moment. Besides, the ABNT NBR $8800: 2008$ [1] procedure of computation of the elastic critical moment is exemplified for a composite beam formed with a cellular steel profile, using the necessary adaptations for the geometric properties and the rotational stiffness.

\section{Proposition of analytical formulation of rotational stiffness of the cellular web}

The method used for the analytical determination of the rotational stiffness of cellular profiles begins with the computation of the transverse displacement of a plate with a circular opening. To obtain this displacement, a simplified model utilizing beam theory and the virtual work principle was used. This model, presented in Figure 8, represents a fixed beam with span equal to the distance between the centers of the top and bottom flanges of the steel profile and with a variable cross section due to the opening. The force is applied on the bottom end of the plate. A single central circular opening was considered on the plate.

The simplified model was divided in three regions for integration, regions 1,2 , and 3 , Figure 9 . The first region goes from the fixed top till the onset of the circular opening, the second encompasses the opening, and the third from the end of the opening to the end of the plate. The need for the model division was the moment of inertia variation due to the opening. The total displacement of the simplified model, $\delta_{2}$, is equal to the sum of the plate displacements, $\delta_{2,1}, \delta_{2,2}$, and $\delta_{2,3}$ corresponding respectively to the lengths $I_{1}, I_{2}$, and $I_{3}$, thus:

$\delta_{2}=\delta_{2,1}+\delta_{2,2}+\delta_{2,3}$

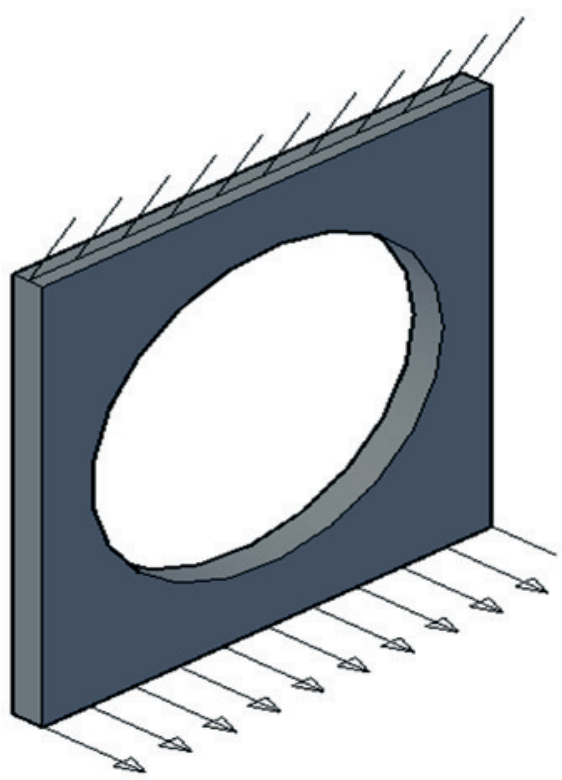

Figure 8

Simplifyed model for analytical formulation 

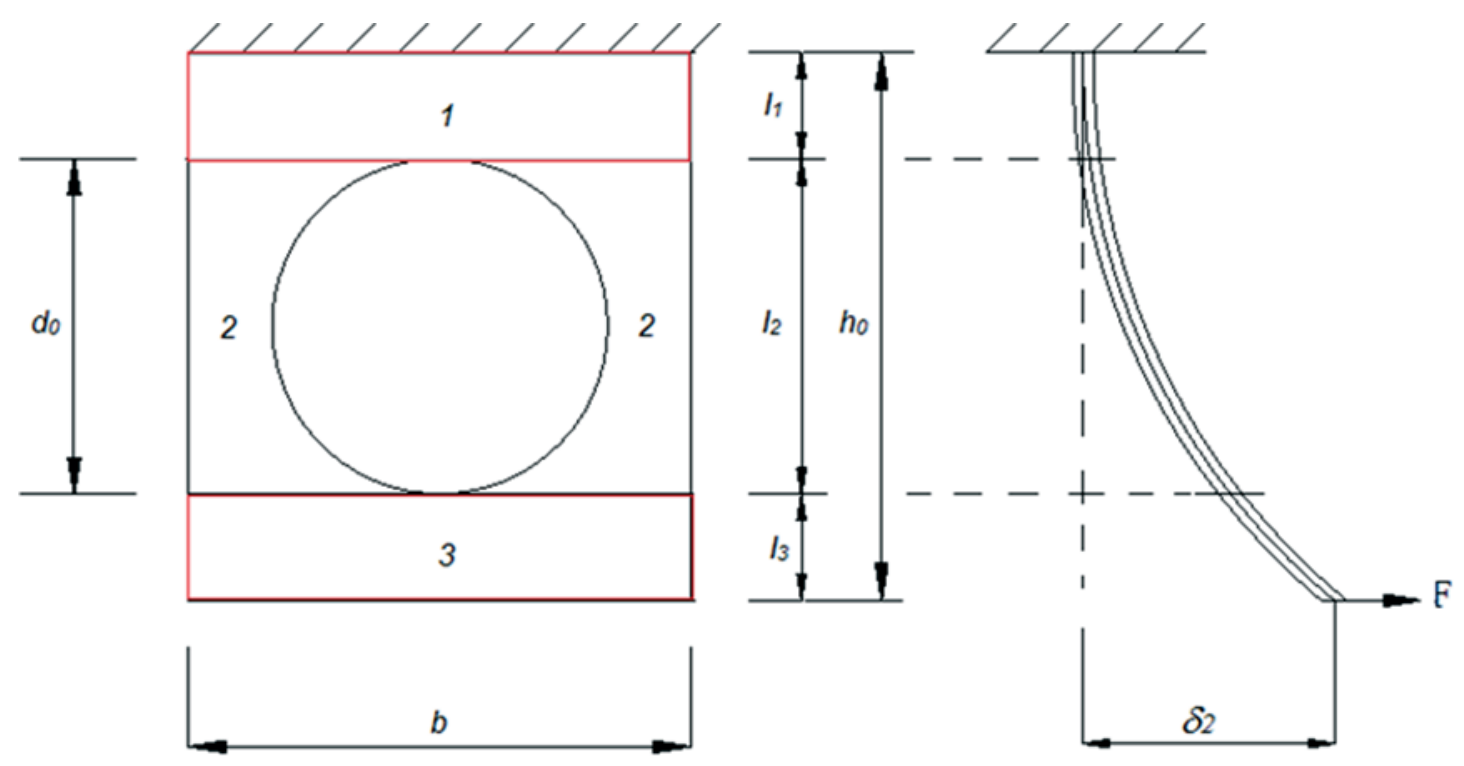

\section{Figure 9}

Regions for integration

To obtain the displacement of the first part, from the fixed end until the beginning of the opening, equation 7 is used.

$\delta_{2,1}=\int_{0}^{\frac{h_{0}-d_{0}}{2}} \frac{F x^{2}}{E I} d x=\frac{F}{24 E I}\left(h_{0}-d_{0}\right)^{3}$

For the third portion, from the end of the opening to the lower end of the web, the procedure is similar to the one for the first portion, since the moment of inertia is constant, and only the integration limits change, therefore:

$\delta_{2,3}=\int_{\frac{h_{0}+d_{0}}{2}}^{h_{0}} \frac{F x^{2}}{E I} d x=\frac{F}{3 E I}\left(h_{0}{ }^{3}-\frac{\left(h_{0}+d_{0}\right)^{3}}{8}\right)$

For the second portion, the integration limits correspond to the diameter of the opening and the displacement equation becomes:

$\delta_{2,2}=\int_{\frac{h_{0}-d_{0}}{2}}^{\frac{h_{0}+d_{0}}{2}} \frac{12 F x^{2}}{E t_{w}^{3}\left(b-2 \sqrt{{\frac{d_{0}}{4}}^{2}-\left(\frac{h_{0}}{2}-x\right)^{2}}\right)} d x$

To solve equation (9) it was necessary to utilize the software MATHEMATICA 10.3 [13]. The software presented a solution with real and complex numbers. After a series of mathematical manipulations, the equation of the second part displacement was obtained.

$\delta_{2,2}$

$$
\begin{aligned}
& =\frac{3 F}{4 E t_{w}^{3}}\left(\left(4 b d_{0}+\pi\left(2 b^{2}-d_{0}{ }^{2}-2 h_{0}^{2}\right)\right)\right. \\
& \left.-\frac{\left(b^{3}-b d_{0}^{2}-b h_{0}^{2}\right)}{\sqrt{b^{2}-d_{0}^{2}}}\left(4 \operatorname{arctg}\left(\frac{d_{0}}{\sqrt{b^{2}-d_{0}^{2}}}\right)+2 \pi\right)\right)
\end{aligned}
$$

Once the individual displacements were obtained, the equation of the displacement of a plate with a central circular opening and a force at the lower end is obtained:

$$
\begin{aligned}
& =\frac{F}{E b t_{w}^{3}}\left(\left(4 h_{0}^{3}-3 d_{0} h_{0}^{3}-d_{0}^{3}\right)\right. \\
& +\frac{3 b}{4}\left(\left(4 b d_{0}+\pi\left(2 b^{2}-d_{0}^{2}-2{h_{0}}^{2}\right)\right)\right. \\
& \left.\left.-\frac{\left(b^{3}-b d_{0}^{2}-b h_{0}^{2}\right)}{\sqrt{b^{2}-d_{0}^{2}}}\left(4 \operatorname{arctg}\left(\frac{d_{0}}{\sqrt{b^{2}-d_{0}^{2}}}\right)+2 \pi\right)\right)\right)
\end{aligned}
$$

A generic model based on the simplified plate with central circular opening model is proposed for the determination of the transverse displacement of a plate with $n$ openings. From the knowledge that the cellular web has several equally spaced openings at a distance $s$ from each other, and that the first and last openings are distant $s_{e}$ from the beam ends, Figure 10, the generic model was generated grouping $n$ central plates of width $s$ to two end plates with width equal to the sum of $s_{e}$ with $0,5 d_{0}$ and $0,5 s$.

The profile web subject to force $F$ at its lower end presents a constant lateral displacement along the beam length, since it is connected to the rigid lower flange. Thus, this work proposes to obtain the lateral displacement of the cellular web with $n$ openings, $\delta_{2, c}$, using a weighed average of the displacements of isolated plates (central and end plates) with respect to their length. The displacements $\delta_{2, \text { cent }}$, and $\delta_{2, \text { ext }}$, are calculated from Equation (11), where the thickness $b$ is taken equal to $s$ for central plates and equal to $s_{e}+0,5 d_{0}+0,5 s$ for end plates. Force $F$ applied 

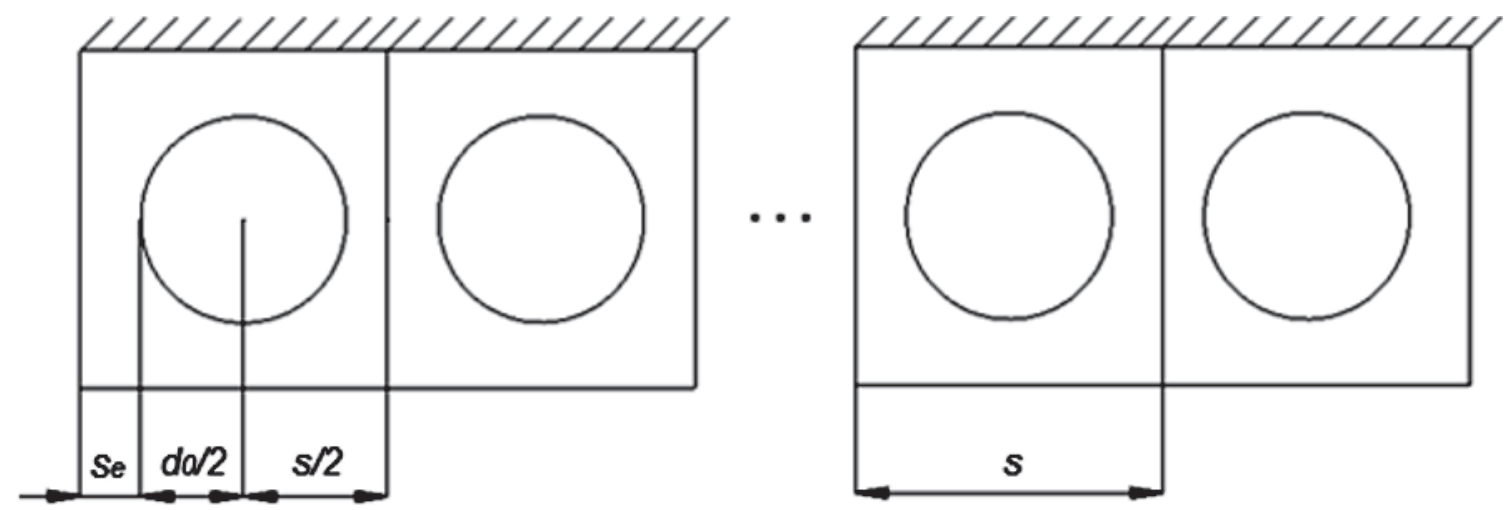

Figure 10

Model for cellular beam with $n$ openings

on the plates should be distributed proportional to each plate length.

$\delta_{2, c}=\frac{2\left(s_{e}+0,5 d_{0}+0,5 s\right) \delta_{2, \text { ext }}+(n-2) s \delta_{2, \text { cent }}}{L}$

Equations 11 and 12 are taken as a basis for the calculation of the torsional stiffness of the cellular profile. Substituting the displacement equation (of one plate and of $n$ plates), it is possible to calculate the rotational stiffness of a beam with one circular opening and with multiple openings, respectively presented on Equations 13 and 14.

$k_{2, \mathrm{c}}=E t_{w}^{3} h_{0}{ }^{2} /\left(4 h_{0}{ }^{3}-3 d_{0} h_{0}{ }^{2}-d_{0}{ }^{3}\right)+\frac{3 b}{4}$

$\left(4 b d_{0}+\pi\left(2 b^{2}-d_{0}^{2}-2 h_{0}^{2}\right)\right.$

$\left.-\frac{\left(b^{3}-b d_{0}{ }^{2}-b h_{0}^{2}\right)}{\sqrt{b^{2}-d_{0}^{2}}}\left(4 \operatorname{arctg}\left(\frac{d_{0}}{\sqrt{b^{2}-d_{0}^{2}}}\right)+2 \pi\right)\right)$

$k_{2, c}=\frac{F h_{0}^{2}}{2\left(s_{e}+0,5 d_{0}+0,5 s\right) \delta_{2, \text { ext }}+(n-2) s \delta_{2, \text { cent }}}$

\section{Numerical evaluation of the cellular web stiffness formulation}

Numerical Models were defined to simulate the behavior of the cellular profile web elastic response by means of the finite element method (Figure 11). The numerical results of lateral displacement of the web plate and, consequently, of its stiffness were obtained and compared with the analytical results. The objective was to evaluate the analytical formulation for its posterior use in the computation of the elastic critical moment of composite beams with cellular profiles. Numerical modeling was accomplished using the finite element analysis software ANSYS 15.0 [14]. Three dimensional finite element plate models were implemented, developed to mirror most realistically the structural behavior of the plates with circular openings. To represent the web of the steel profile, SHELL181 shell elements were used. SHELL 181 is recommended to model thin to moderately thick structures, being useful for linear and nonlinear analyses, with large displacements and large strains, ANSYS 15.0 [14]. This element is defined by four nodes and six degrees of freedom at each node: translations and rotations on the three orthogonal directions. Several authors have used SHELL 181 element in numerical models of steel profile beams and composite steel and concrete beams for linear, nonlinear, and buckling analyses. Among them, works from Abreu [15], Calenzani [4], and Oliveira [3] can be cited.

The steel cellular profile web yield stress was taken as $34.5 \mathrm{kN} /$ $\mathrm{cm}^{2}$. Poisson's coefficient and Young's modulus were taken as 0.3 e $20,000 \mathrm{kN} / \mathrm{cm}^{2}$, respectively.

To simulate the boundary conditions, at the top end of the cellular web, displacements and rotations on the global directions $x, y$, and $z$ were restricted. At the bottom end, the displacement of the nodes was coupled, in such a way as that the displacement was equal through the length of the model, simulating the bottom flange. This restriction was placed to consider the diaphragm effect proportioned by the bottom flange, which was not modeled. The load was distributed to the nodes on the inferior end of the plate for better convergence of the model. The total force intensity applied to the model was $10 \mathrm{kN}$.

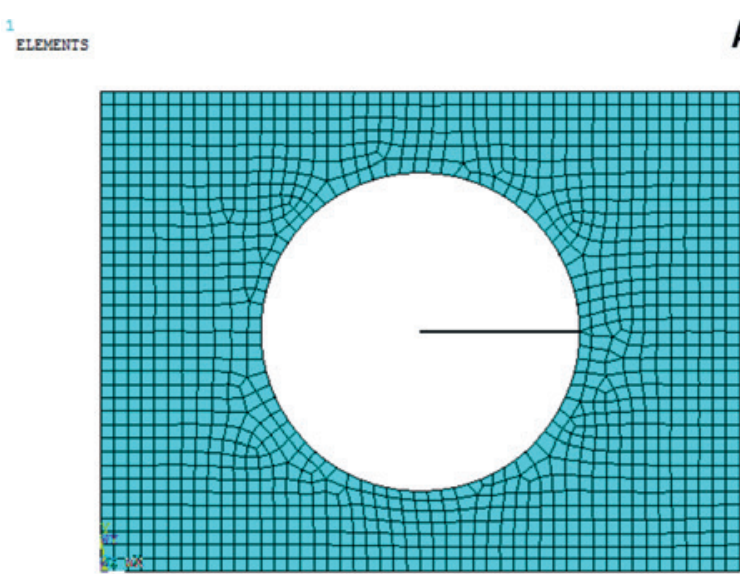

Figure 11

Numerical model of the cellular plate - frontal 
Table 1

Mesh study

\begin{tabular}{|c|c|c|c|}
\hline $\begin{array}{c}\text { Element } \\
\text { size } \\
(\mathbf{m})\end{array}$ & $\begin{array}{c}\delta_{\text {máx }} \\
(\mathbf{m})\end{array}$ & $\begin{array}{c}\text { Number of } \\
\text { elements }\end{array}$ & $\begin{array}{c}\text { Deviation } \\
\left(\delta_{i}-\delta_{i+1}\right) / \delta_{i}\end{array}$ \\
\hline 0.01 & 0.1189 & 1096 & 0.0017 \\
\hline 0.015 & 0.1187 & 498 & 0.0025 \\
\hline 0.02 & 0.1184 & 291 & 0.0017 \\
\hline 0.025 & 0.1182 & 195 & 0.0034 \\
\hline 0.03 & 0.1178 & 128 & 0.0025 \\
\hline 0.035 & 0.1175 & 114 & 0.0043 \\
\hline 0.04 & 0.1170 & 81 & 0.0051 \\
\hline 0.045 & 0.1164 & 71 & 0.0069 \\
\hline 0.05 & 0.1156 & 58 & -0.0043 \\
\hline 0.055 & 0.1161 & 37 & 0.0000 \\
\hline 0.06 & 0.1161 & 37 & 0.0121 \\
\hline 0.065 & 0.1147 & 30 & 0.0044 \\
\hline 0.07 & 0.1142 & 28 & 0.0149 \\
\hline 0.075 & 0.1125 & 30 & -0.0027 \\
\hline 0.08 & 0.1128 & 26 & 0.0168 \\
\hline 0.085 & 0.1109 & 23 & 0.0469 \\
\hline 0.09 & 0.1057 & 23 & 0.0000 \\
\hline 0.095 & 0.1057 & 23 & -0.0095 \\
\hline 0.1 & 0.1067 & 21 & - \\
\hline & & & \\
\hline
\end{tabular}

ANSYS 15.0 [14] has two alternatives for finite element mesh generation, free or mapped. The finite element mesh was set to free, instead of mapped, for implementation simplicity. To determine the ideal mesh size a specific model of a W200×26.6 profile, adapted for a cellular profile with one opening, was used. This model is 0.3228 $\mathrm{m}$ high, $0.4306 \mathrm{~m}$ long and with an opening diameter of $0.2153 \mathrm{~m}$. The meshes were generated with elements from 0.01 to $0.1 \mathrm{~m}$ side (varying the element size in $5 \mathrm{~mm}$ increments). The displacement results in the direction normal to the plate were recorded, as well as the number of elements in each model. From these data, the relative deviation between two consecutive attempts was calculated. The obtained values are presented in Table 1.

Figure 12 presents the plot of maximum displacement versus the number of elements for each of the analyzed models. It can be observed by the asymptotic behavior that convergence of the results occurs after a displacement of $0.118 \mathrm{~m}$. One point, corresponding to a 71 element mesh, gave a displacement result different from the curve pattern, showing an oscillation of the numerical result, but it does not compromise the validity of the mesh study developed since it is a small perturbation on a single point. From the analyzed results, the utilized mesh was then set to $0.01 \mathrm{~m}$. This mesh presented results with adequate precision and, though more refined than that which already presented good solution convergence, did not require high computer processing time.

Linear geometric and material analyses were considered in the process of algebraic development of the equation for the determination of rotational stiffness of the cellular web. Therefore, to be able to compare the analyses, the finite element analysis was also executed using linear behavior. The linear analyses, for the numerical and theoretical approaches, are justified since the standard design methods also consider linear elastic behavior.

For validation of the analytical formulation with the numerical results three different laminated profiles were selected for generation of cellular profiles. The choice of the laminated wide flange profiles was made such as to encompass the whole range of heights in the catalog of the Brazilian producer Gerdau Açominas. This analysis covered twelve models with geometric characteristics obtained after a standard predefined model.

It is customary to use the proposal of Harper apud Abreu [15] for the constructive parameters limits of cellular profiles, in which the opening diameter $\left(d_{0}\right)$ varies between a fraction 0.57 and 0.8 of the cellular profile height $(d)$ and the spacing between openings $(s)$ varies from a relation 1.08 to 1.5 of the opening diameter. Thus, the cellular profile of the standard model had the constructive parameters: expanded profile height $(d)$, diameter of the circular

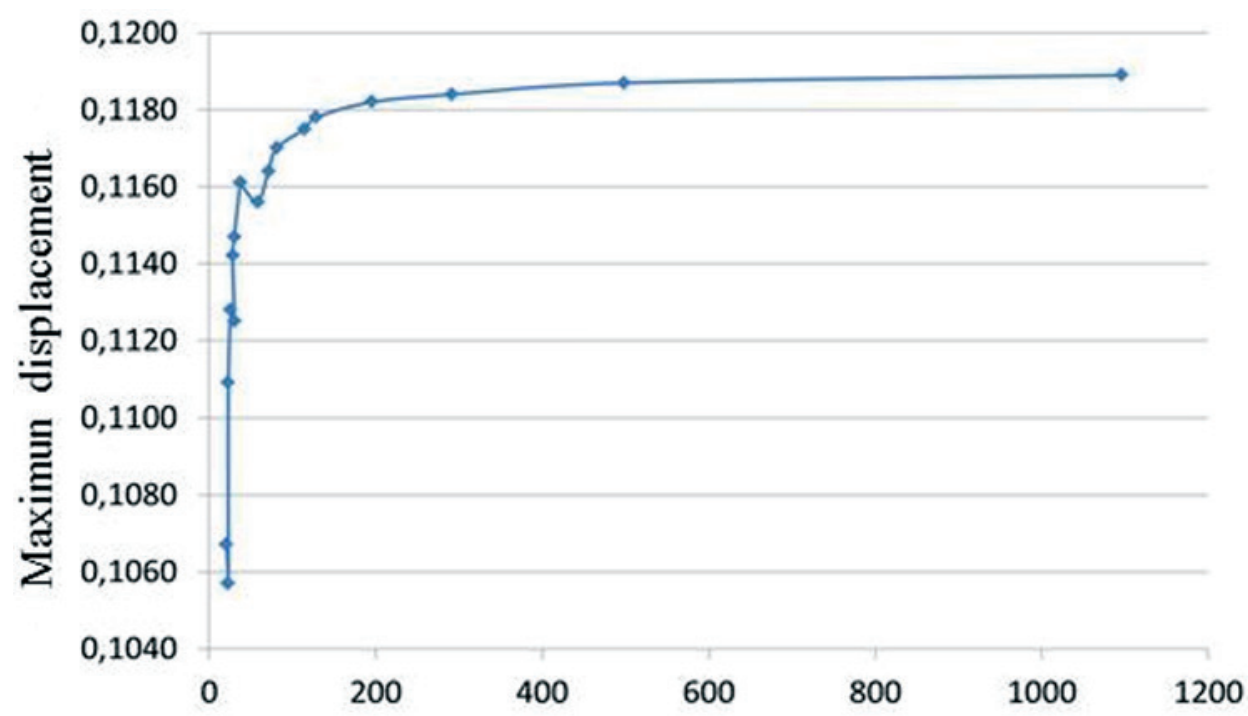

Figure 12

Number of elements

Maximum displacement $\mathrm{x}$ number of elements 
opening in the profile web $\left(d_{0}\right)$, spacing between openings $(s)$, distance between the profile end, and the first circular opening $\left(s_{e}\right)$, selected according to Table 2 .

The laminated profiles selected are presented at Table 3 along with the geometric parameters adopted for the cellular profiles. In each cellular profile, the number of openings in its web was varied and, consequently, its total length. The models presented one, ten, twenty, and thirty openings.

Once the models were established, a symbology for identification of the cellular web models was created, e.g.: Cprofile_d $d / d_{g \_} d_{0} / d_{-} s / d_{0 \_} s_{e} / d_{0} n$, where Cprofile indicates the cellular beam with the designation of the original profile and the variables $d, d_{g}, d_{0}, s, s_{e}$, and $n$ are the geometric properties. C200x26.6_1.6_0.65_1.3_0.5_1, for example, mean a cellular beam with original profile $W 200 \times 26.6$, ratio between the final height and the original profile height, $d / d_{g}$, equal to 1.6 , ratio between the opening diameter and the final height, $d_{\delta} / d$, equal to 0.65 , ratio between the opening distance and the opening diameter, $s / d_{0}$, equal to 1.3 , ratio between the distance from the

\section{Table 2}

Standard model

\begin{tabular}{|c|c|c|c|c|}
\cline { 2 - 5 } \multicolumn{1}{c|}{} & $\mathbf{d}$ & $\mathbf{d}_{\mathbf{0}}$ & $\mathbf{s}$ & $\mathbf{s}_{\mathbf{e}}$ \\
\hline $\begin{array}{c}\text { Standard } \\
\text { model }\end{array}$ & $1.6^{*} \mathrm{dg}$ & $0.65^{*} \mathrm{~d}$ & $1.3^{*} \mathrm{~d}_{0}$ & $0.5^{*} \mathrm{~d}_{0}$ \\
\hline
\end{tabular}

end to the first opening and the opening diameter, $s_{e} / d_{0}$, equal to 0.5 , and, last, the number of openings.

To evaluate the analytical equation, the numeric model results were compared with those from the rotational stiffness of the cellular web formulation. Table 4 presents the analyzed profiles, the analytical displacement obtained by the proposed formulation, the numerical displacement, the analytical rotational stiffness of the cellular web, the numerical rotational stiffness of the cellular web, and the relative difference between the stiffness values.

The difference of approximately $8 \%$ from the analytical formulation with respect to the numerical results can be attributed to the

Table 3

Profiles for validation of the analitical formulation

\begin{tabular}{|c|c|c|c|c|c|c|}
\hline Models & $\mathbf{n}$ & $\begin{array}{c}\mathbf{d} \\
(\mathbf{m})\end{array}$ & $\begin{array}{c}\mathbf{d}_{\mathbf{o}} \\
(\mathbf{m})\end{array}$ & $\begin{array}{c}\mathbf{s} \\
(\mathbf{m})\end{array}$ & $\begin{array}{c}\mathbf{s}_{\text {e }} \\
(\mathbf{m})\end{array}$ & $\begin{array}{c}\mathbf{L} \\
(\mathbf{m})\end{array}$ \\
\hline \multirow{4}{*}{$200 \times 26,6$} & 1 & 0.331 & 0.215 & 0.279 & 0.107 & 0.431 \\
\cline { 2 - 7 } & 10 & 0.331 & 0.215 & 0.279 & 0.107 & 2.949 \\
\cline { 2 - 7 } & 20 & 0.331 & 0.215 & 0.279 & 0.107 & 5.748 \\
\cline { 2 - 7 } & 30 & 0.331 & 0.215 & 0.279 & 0.107 & 8.547 \\
\hline \multirow{4}{*}{$410 \times 60$} & 1 & 0.651 & 0.423 & 0.550 & 0.212 & 0.847 \\
\cline { 2 - 7 } & 10 & 0.651 & 0.423 & 0.550 & 0.212 & 5.799 \\
\cline { 2 - 7 } & 20 & 0.651 & 0.423 & 0.550 & 0.212 & 11.302 \\
\hline \multirow{4}{*}{$610 \times 125$} & 30 & 0.651 & 0.423 & 0.550 & 0.212 & 16.804 \\
\cline { 2 - 7 } & 1 & 0.979 & 0.636 & 0.827 & 0.318 & 1.273 \\
\cline { 2 - 7 } & 20 & 0.979 & 0.636 & 0.827 & 0.318 & 8.720 \\
\cline { 2 - 7 } & 30 & 0.979 & 0.636 & 0.827 & 0.318 & 16.994 \\
\hline
\end{tabular}

Table 4

Comparison of the analitical and numerical results for the stiffness of cellular web

\begin{tabular}{|c|c|c|c|c|c|}
\hline Symbology & $\begin{array}{l}\delta_{2, \mathrm{c}} \mathrm{A} \\
(\mathrm{m})\end{array}$ & $\begin{array}{l}\delta_{2, \mathrm{CN}} \\
(\mathrm{m})\end{array}$ & $\begin{array}{c}\mathbf{k}_{2 \mathrm{c} A} \\
(\mathrm{kN} / \mathrm{rad})\end{array}$ & $\begin{array}{c}k_{2 c N} \\
(k N / r a d)\end{array}$ & $\begin{array}{c}\text { Deviation } \\
\left(k_{2 c A} / k_{2 c N}\right)\end{array}$ \\
\hline C200x26.6_1.60_0.65_1.3_0.5_1 & 0.331 & 0.215 & 0.279 & 0.107 & 0.431 \\
\hline C200×26.6_1.60_0.65_1.3_0.5_10 & 0.331 & 0.215 & 0.279 & 0.107 & 2.949 \\
\hline C200×26.6_1.60_0.65_1.3_0.5_20 & 0.331 & 0.215 & 0.279 & 0.107 & 5.748 \\
\hline C200x26.6_1.60_0.65_1.3_0.5_30 & 0.331 & 0.215 & 0.279 & 0.107 & 8.547 \\
\hline C410x60.0_1.60_0.65_1.3_0.5_1 & 0.651 & 0.423 & 0.550 & 0.212 & 0.847 \\
\hline C410×60.0_1.60_0.65_1.3_0.5_10 & 0.651 & 0.423 & 0.550 & 0.212 & 5.799 \\
\hline C410x60.0_1.60_0.65_1.3_0.5_20 & 0.651 & 0.423 & 0.550 & 0.212 & 11.302 \\
\hline C410x60.0_1.60_0.65_1.3_0.5_30 & 0.651 & 0.423 & 0.550 & 0.212 & 16.804 \\
\hline C610x125.0_1.60_0.65_1.3_0.5_1 & 0.979 & 0.636 & 0.827 & 0.318 & 1.273 \\
\hline C610x125.0_1.60_0.65_1.3_0.5_10 & 0.979 & 0.636 & 0.827 & 0.318 & 8.720 \\
\hline C610x125.0_1.60_0.65_1.3_0.5_20 & 0.979 & 0.636 & 0.827 & 0.318 & 16.994 \\
\hline C610x125.0_1.60_0.65_1.3_0.5_30 & 0.979 & 0.636 & 0.827 & 0.318 & 25.268 \\
\hline
\end{tabular}




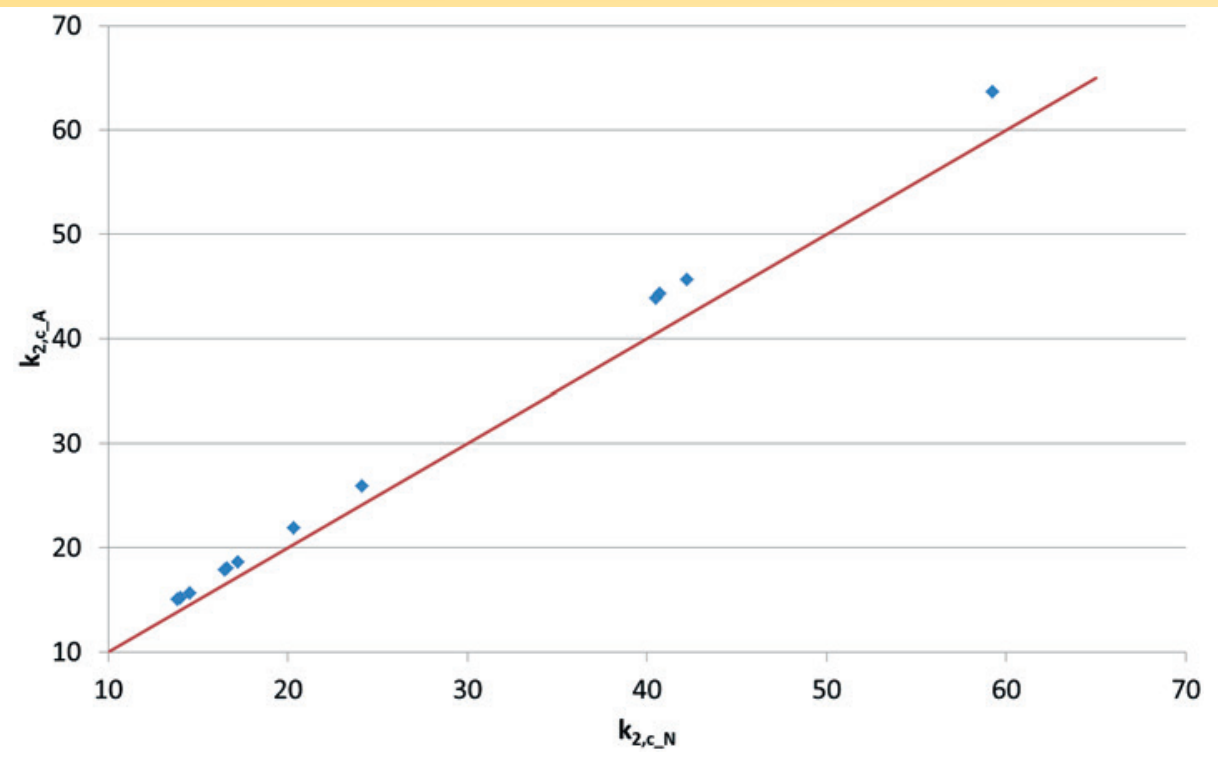

Figure 13

Perfect fit line

adopted simplifications on the analytical calculation of the web displacement, in which linear element theory was used and the displacement due to shear force was neglected. The software tends

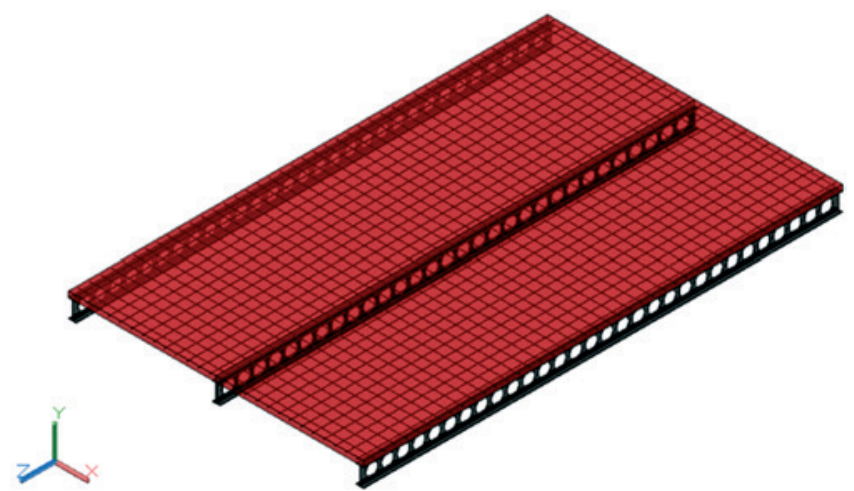

\section{Figure 14}

Composite beams with cellular web profile continuous U mechanism to concentrate the applied forces on the places where stiffness is higher (solid web sections) while the equation distributes the applied force on the cellular plate evenly, proportional to the plate length. Additionally, the numerical analysis considered plate and shell theory, and the displacements are computed including all the applied loading.

Figure 13 presents the plot of the perfect fit line for the numerical and analytical rotational stiffness results of the twelve studied models. It can be observed that the calculated values have good agreement with the numerical data. All the points were very close to the perfect fit line, though slightly above it, pointing towards the need for an equation adjustment by means of a reduction coefficient. It is recommended, then, the use of the analytical equation herein developed for the computation of the rotational stiffness of the cellular web with a $10 \%$ reduction coefficient. Therefore, the proposed formulation for the rotational stiffness of a cellular web with $n$ openings is:

$k_{2, c}=\frac{0,9 F h_{0}^{2}}{2\left(s_{e}+0,5 d_{0}+0,5 s\right) \delta_{2, \text { ext }}+(n-2) s \delta_{2, \text { cent }}}$

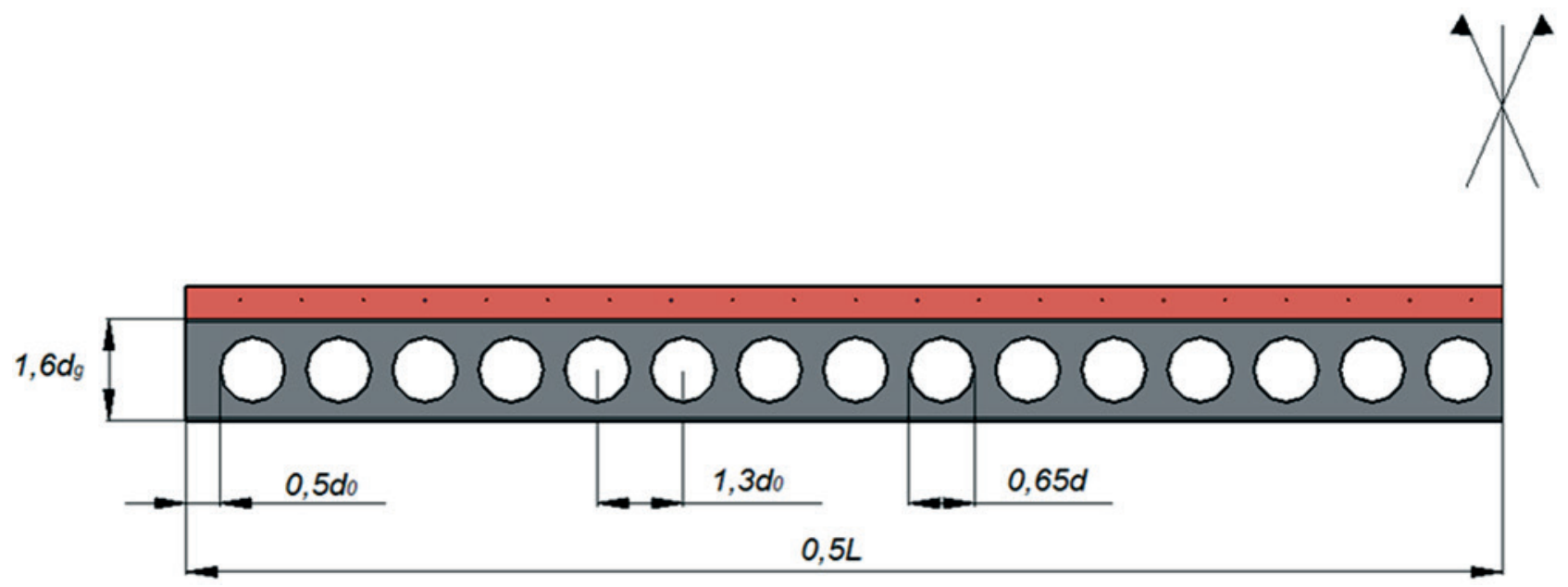

Figure 15

Standard model - lateral view 


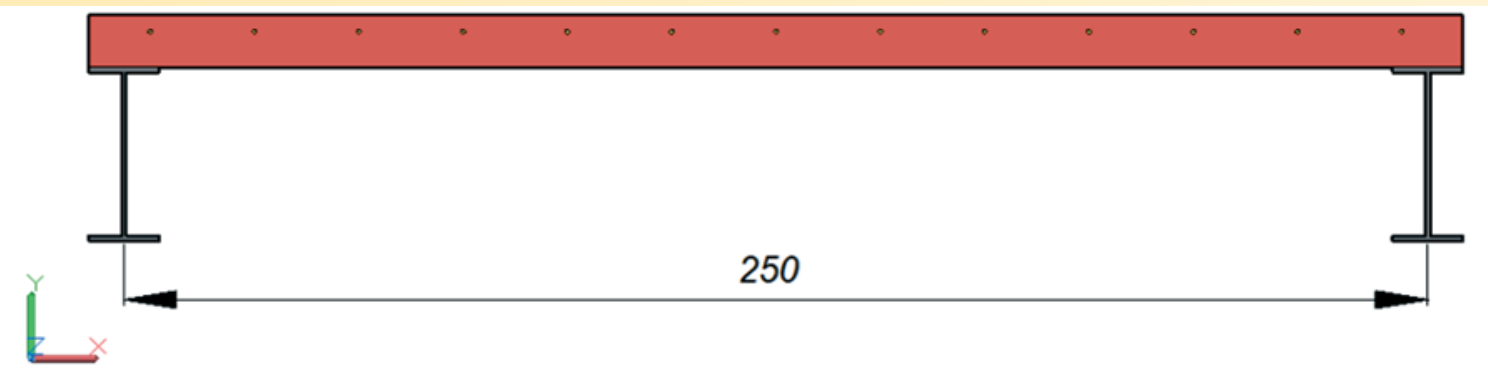

Figure 16

Standard model - distance between beams

\section{Numerical example of computation of the elastic critical moment}

In this section, the LTB elastic critical moment of two steel and concretcomposite beams, one with a cellular profile and the other with a solid web profile of equivalent height. The influence of the web openings on the rotational stiffness values and the elastic critical moment was evaluated.

The composite beam with cellular profile was built with the previously studied W200x26.6 laminated profile. The adopted number of web openings was 30 (thirty), which made the span of the composite beam slightly higher than $25 d$, where $d$ is the cellular profile height. Thus, both composite beams, of cellular and solid web profiles, had a span of $8.55 \mathrm{~m}$ and the height of the steel profile equal to $331.2 \mathrm{~mm}$ (ratio $d / d_{g}=1.6$ ). The composite beams were denominated VC 331.2 and VP 331.2, respectively for the cellular profile and the solid web profile.

The slab used on both beams is bulk reinforced concrete $10 \mathrm{~cm}$ high. The longitudinal hogging reinforcement was considered having $12.5 \mathrm{~mm}$ diameter at every $15 \mathrm{~cm}$ and the transverse reinforcements were both of $6.3 \mathrm{~mm}$ diameters at every $20 \mathrm{~cm}$. The concrete cover is $3 \mathrm{~cm}$ for the upper longitudinal and lower transverse reinforcements and $4.2 \mathrm{~cm}$ for upper transverse reinforcement. Young's modulus for the steel and concrete are, respectively, 200,000 MPa and 23,800 MPa. The yielding stress for the steel profile and the reinforcement are, respectively, $345 \mathrm{MPa}$ and $500 \mathrm{MPa}$. In this example, the transverse distance between composite beams is $250 \mathrm{~cm}$, and it was chosen to determine the elastic critical moment of an inner beam, as can be seen at Figures 14,15 , and 16 .

For the computation of the slab rotational stiffness, according to ABNT NBR 8800:2008 [1], a length of one meter along the transverse direction from the beam axis was considered, such that a rotational stiffness per unit length is obtained. Thus, five bars for the transverse reinforcement, positive and negative, fit within this length. The steel areas of the transverse bars, in 1 meter of the slab, add to $1.55 \mathrm{~cm}^{2}$. Transforming the concrete section in steel, the width of the slab and the transformed inertia, ignoring the concrete in tension, are $11.9 \mathrm{~cm}$ and 0.395 $\mathrm{cm}^{2} / \mathrm{cm}$, respectively. The flexural stiffness of the homogenized composite section by unit length of the beam is calculated taking the least value, considering the half-span of the slab, for positive moment, and an internal support, for hogging moment. In this case, both moments of inertia are equal, since both the reinforcements, positive and negative, have the same area. Thus, $(E I)_{2}$ is equal to $7,900 \mathrm{kN} / \mathrm{cm}$. Therefore, according to Equation 3, given by ABNT NBR 8800:2008 [1], the flexural stiffness of the homogenized composite section, adopting a equal to 3 for representing internal beams.

$k_{1}=3 x \frac{7900}{250}=94,8 \mathrm{kN} / \mathrm{rad}$

After the computation of the rotational stiffness of the slab, the rotational stiffness for both the solid web and the cellular profiles was obtained. For the solid web, Equation 4 of ABNT NBR $8800: 2008$ [1] was used, with web thickness equal to $5.8 \mathrm{~mm}$ and the distance between top and bottom flange centers of gravity equal to $322.8 \mathrm{~mm}$.

$$
k_{2}=\frac{20000 \cdot 0,58^{3}}{3 \cdot 32,28 \cdot\left(1-0,3^{2}\right)}=33,21 \mathrm{kN} / \mathrm{rad}
$$

For the cellular web, the proposed formulation (Equation 15) was used and the stiffness value was $13.55 \mathrm{kN} / \mathrm{rad}$.

Table 5 presents the rotational stiffness results of the slab, $k_{1}$, of the webs, cellular, $k_{2, c}$, and solid, $k_{2, p}$, and the rotational stiffness of the composite beams, $k_{r, c}$ for cellular profile and $k_{r, p}$ for solid web profile. The rotational stiffness of the composite beams was obtained by the equivalent stiffness equation for springs serially connected. It can be noted that the presence of openings in the cellular profile reduces the composite beam stiffness in $51.8 \%$.

ABNT NBR 8800:2008 [1] procedure was followed to compute the elastic critical moment, as stated in Equation 5. For the computation of the geometric properties of the composite beam with the cellular profile was used the cross section of the cellular profile at the center of the opening, what consists in two Ts (one called top T and

Table 5

Comparison of the rotational stiffness of composite beams with cellular and solid web profiles

\begin{tabular}{|c|c|c|c|c|c|c|c|}
\hline Profile & $\mathrm{n}$ & $\begin{array}{c}\mathrm{h}_{0} \\
(\mathrm{~m})\end{array}$ & $\begin{array}{c}\mathrm{L} \\
(\mathrm{m})\end{array}$ & $\begin{array}{c}k_{1} \\
(k N / \text { rad })\end{array}$ & $\begin{array}{c}k_{2, c} \\
(k N / r a d)\end{array}$ & $\begin{array}{c}k_{k_{\text {ric }}} \\
(\mathrm{kN} / \mathrm{rad})\end{array}$ & \\
\hline VC331.2 & 30 & 0.323 & 8.546 & 94.800 & 13.553 & 11.858 & \\
\hline Profile & $\mathrm{n}$ & $\begin{array}{l}\mathrm{h}_{0} \\
(\mathrm{~m})\end{array}$ & $\begin{array}{l}L \\
(m)\end{array}$ & $\begin{array}{c}k_{1} \\
(k N / r a d)\end{array}$ & $\begin{array}{c}k_{2, p} \\
(k N / r a d)\end{array}$ & $\begin{array}{c}k_{\mathrm{rip}} \\
(\mathrm{kN} / \mathrm{rad})\end{array}$ & $\begin{array}{c}\text { Ratio } \\
\left(k_{\mathrm{r}, \mathrm{c}} / \mathrm{k}_{\mathrm{r}, \mathrm{p}}\right)\end{array}$ \\
\hline VP331.2 & 0 & 0.323 & 8.546 & 94.800 & 33.211 & 24.595 & 0.482 \\
\hline
\end{tabular}


the other bottom T). For the composite beam with the solid web, of constant cross section along the span, the geometric properties of the I section were used, such as in Figure 17 (a) and (b).

The hogging moment diagram was considered constant, such that $\psi$ is equal to 1 and $C_{\text {dist }}$ is equal to 6.2 . With all the remaining parameters calculated, it was possible to find the elastic critical moment of the composite beams under study. The results are presented in Table 6. It can be noticed that the presence of openings in the cellular profile reduces the elastic critical moment value in approximately $32.4 \%$.

\section{Conclusion}

In this work, a formulation for the determination of the rotationa stiffness of the cellular web was presented and studied. Furthermore, its application on the computation of the elastic critical moment of composite beams with cellular profile was presented, based on the inverted U-frame mechanism. This formulation was derived from the Principle of Virtual Work, and determined the rotational stiffness of the cellular profile web after the lateral displacement of a plate with a circular centered opening with height equal to the distance between the centroids of the top and bottom flanges. To validate the equation, numerical modeling using the Finite Element Method was implemented to obtain the lateral displacement of the cellular profile web by means of an elastic analysis.

The stiffness results from the analytical formulation of the cellular web were always superior to the numerical, but the relative deviation was never above $10 \%$. Therefore, a reduction coefficient of 0.9 was proposed for the cellular profile web stiffness equation. To exemplify, the developed formulation was used to determine the rotational stiffness and with it the LTB elastic critical moment of a composite beam with cellular profile built from the W200x26.6 profile. The values of rotational stiffness and elastic critical moment of this beam and of another composite beam with equivalent height and with a solid web were compared. It was observed that the rotational stiffness of the cellular web composite beam is $48.2 \%$ the stiffness of the solid web composite beam. The composite beam with cellular profile had an elastic critical moment $32.4 \%$ smaller than the solid web beam.

It was attempted to take into consideration all factors involved in the LTB of composite beams with cellular profiles, due to concerns of reliability of the developed formulation. As the number of cases covered in this research was limited, further investigation is necessary to assure the generality of the proposal.

\section{Acknowledgements}

Table 6

Comparison of the elastic critical moment of composite beams with cellular and solid web profiles

\begin{tabular}{|c|c|c|c|c|c|c|}
\hline Profile & $\mathrm{n}$ & $\begin{array}{c}\mathrm{h}_{0} \\
(\mathrm{~m})\end{array}$ & $\begin{array}{c}\mathrm{L} \\
(\mathrm{m})\end{array}$ & $\begin{array}{c}k_{\mathrm{rc}} \\
(\mathrm{kN} / \mathrm{rad})\end{array}$ & $\begin{array}{c}M_{\mathrm{cr}, \mathrm{c}} \\
(\mathrm{kNCm})\end{array}$ & \\
\hline VC331.2 & 30 & 0.323 & 8.546 & 11.858 & 14721.933 & \\
\hline Profile & $n$ & $\begin{array}{l}h_{0} \\
(\mathrm{~m})\end{array}$ & $\underset{(m)}{L}$ & $\begin{array}{c}k_{\mathrm{rp}} \\
(\mathrm{kN} / \mathrm{rad})\end{array}$ & $\underset{(\mathrm{kNcm})}{M_{\mathrm{crp}}}$ & $\begin{array}{c}\text { Ratio } \\
\left(M_{c r, c} / M_{c r, p}\right)\end{array}$ \\
\hline VP331.2 & 0 & 0.323 & 8.546 & 24.595 & 21785.558 & 0.676 \\
\hline
\end{tabular}

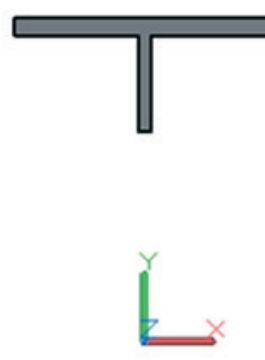

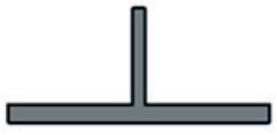

(4) Cellular profile

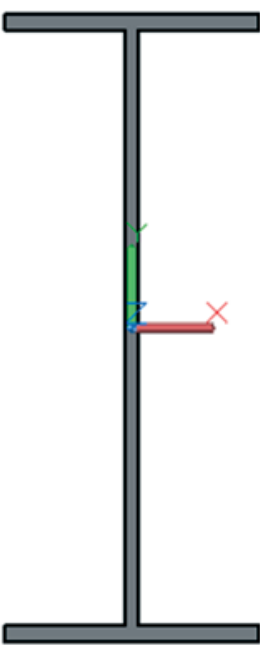

B

Solid web profile

\section{Figure 17}

Cross section considered in the computation of the geometric properties

The authors would like to thank Conselho Nacional de Desenvolvimento Científico e Tecnológico (CNPq), Coordenação de Aperfeiçoamento de Pessoal de Nível Superior (CAPES), Fundação de Amparo à Pesquisa do Espírito Santo (FAPES) for the support received during the development of this research.

\section{References}

[1] ASSOCIAÇÃO BRASILEIRA DE NORMAS TÉCNICAS. NBR 8800: Projeto de estruturas de aço e de estruturas mistas de aço e concreto de edifícios. Rio de Janeiro, 2008. (in Portuguese)

[2] CEN, EN 1994-1-1:2004. EUROCODE 4: Design of composite steel and concrete structures - Part 1-1: general rules and rules for buildings. Brussels, Belgium, 2004.

[3] OLIVEIRA, J. P. S., CALENZANI, A. F. G., FAKURY, R. H., FERREIRA, W. G. Elastic critical moment of continuous composite beams with a sinusoidal-web steel profile for lateral-torsional buckling. Engineering Structures, n. 113, p. 121-132, 2016.

[4] CALENZANI, A.F.G. Proposição de procedimento para a determinação da rigidez rotacional de vigas mistas 
contínuas e semicontínuas com perfis de alma senoidal. Doctoral Dissertation (Doutorado em Engenharia de Estruturas), Pós-Graduação em Engenharia de Estruturas, Universidade Federal de Minas Gerais, Belo Horizonte, 2008. (in Portuguese)

[5] FAN, C.K.R. Buckling in continuous composite beams. Thesis (Doctor of Philosophy), Department of Engineering, University of Warwick, U.K., 1990.

[6] JOHNSON, R.P. Composite Structures of Steel and Concrete: beams, slabs, columns and frames for buildings. 3. ed. Warwick, U.K: Blackwell, 2004.

[7] JOHNSON, R.P., MOLENSTRA N. Strength and stiffness of shear connections for discrete U-frame action in composite plate girders. The Structural Engineer, V.68, n.19/2, p.:386392, 1990.

[8] CALENZANI, A.F.G.; FAKURY, R.H.; PAULA, F.A.; RODRIGUES, F.C.; QUEIROZ, G.; PIMENTA, R.J. Rotational stiffness of continuous composite beams with sinusoidalweb profiles for torsional buckling. Journal of Constructional Steel Research, n.79, p. 22-33, 2012.

[9] ROIK, K.; HANSWILLE, G.; KINA, J. Solution for the lateral torsional buckling problem of composite beams. Stahlbau, 59, $327-332,1990$.

[10] LAWSON, R. M.; HICKS, S. J. - Design of composite beams with large web openings: in accordance with Eurocodes and the UK National Annexes. Steel Construction Institute, 2011.

[11] WARD, J. K. Design of composite and non-composite cellular beams. Steel Construction Institute, 1990.

[12] Gizejowski, M.A.; Khalil, W.A.S. Stability and ductility of castellated composite beams subjected to hogging bending. International Conference on Stability and Ductility of Steel Structures, Rio de Janeiro, Brazil, p. 839-846, 2010.

[13] Wolfram Research, Inc., Mathematica, Version 10.3, Champaign, IL (2015).

[14] ANSYS, INC. Release 15.0 Documentation for ANSYS. Canonsburg: [s.n.], 2013.

[15] ABREU, L. M. P.; FAKURY, R. H.; CASTRO e SILVA, A. L. $R$. Determinação do momento fletor resistente à flambagem lateral com torção de vigas de aço celulares, Mecânica Computacional, v. XXIX, p. 7255-7271, 2010. (in Portuguese) 